\title{
Effect of Riffle Sequences on Discharge and Sediment Transport in a Mountain Stream
}

\author{
Joanna Korpak' ${ }^{1}$ Anna Lenar-Matyas ${ }^{1}$, Marta Łapuszek ${ }^{1 *}$, Andrzej Mączałowski ${ }^{1}$ \\ 1 Department of Engineering and Water Management, Cracow University of Technology, \\ Warszawska 24, 31-155 Kraków, Poland \\ * Corresponding author's e-mail: mlapusze@iigw.pl
}

\begin{abstract}
Natural riffles are formed as a result of fluvial processes in the stream channel, water flow, and sediment movement. In recent years, artificial riffles have also been constructed in order to improve the water flow and sediment transport as well as to initiate the processes that lead to the restoration of natural riffle-pool sequences. In river engineering, the utilization of artificial riffles (rapid hydraulic structures) is still in its experimental stage. Artificial riffles are studied and described in the literature on a case study basis. However, the studies on riffle sequences and their effects on stream channel evolution need to be improved. A system of artificial riffles was created in the mouth section of Krzczonówka Stream in 2013. The new riffles made the stream channel more morphologically diverse and also reduced its longitudinal slope. The check dam on the stream, located upstream of the newly formed riffles, was renovated and lowered in 2014. At this time, a flood occurred and released a large mass of sediment downstream of the check dam. Then, the sediment settled in the sections between the artificial riffles, thus covering some of them. The aim of the study was to examine the effect of the system of riffles on the changes in sediment transport and water flow in the studied stream channel. Calculations indicate that the system of riffles established downstream of the check dam has limited the movement of sediment. The sediment transport is varied throughout the studied stream course and is mostly dependent on the sediment supply.
\end{abstract}

Keywords: mountain stream, riffles, rapid hydraulic structure, sediment transport

\section{INTRODUCTION}

Riffles occur naturally in river channels and are formed by fluvial processes as well as the energy of flowing water and sediment movement. Riffle-pool systems occur mainly in sinuous foothills and mountain rivers with a gravel bed. This type of system is characterized by the hydrodynamic balance or excess transport in relation to the influx [Bojarski et al. 2005]. Sinuous streams produce bends where pools form near the concave bank, while the sites where the current shifts between bends are characterized by riffles.

Artificial riffles have been constructed in recent years in order to improve the water flow and sediment transport as well as to initiate the processes leading to the restoration of natural channel landforms [Plesiński and Radecki-Pawlik 2018a, b]. They are designed to mimic natural riffles, but are characterized by a greater regularity and structural stability. Artificial riffles are also rougher than the natural ones and span the entire river channel. Water flow strongly accelerates in the riffle area [Mooney 2007, Plesiński and Radecki-Pawlik 2018a, b]. Increased roughness is attained via the use of broken rocks with a large diameter across the artificial riffle area the rocks dissipate the energy of flowing water. The use of riffles is slowly replacing the use of traditional drop structures and low head dams, which is due to the new environmental regulations. Well-designed manmade riffles do not prevent fish from migrating upriver. In addition, they improve the oxygen conditions in the river, foster river self-cleaning processes, and are not an aesthetic eyesore [Bojarski et al. 2015, Torre 
2001]. Two important ecological benefits of the use of riffle-pool systems are the differences in the stream bed gradient from site to site and the presence of coarse particles, which creates proper conditions for the water development of flora and fauna [Lapuszek and Lenar-Matyas 2013, Torre 2001]. Another positive aspect of the use of this type of structure is the improvement in the hydrodynamic conditions in the stream of interest and protection of river channel from deepening [Radecki-Pawik 2011]. An artificial riffle reduces unit stream power both in the overspill of the riffle and the end of the pool [Bezzola et al. 1986]. This reduces the sediment transport and in effect reduces the riverbed erosion. This process is most significant in regulated river channels.

While the general advantages of riffles are widely known, many specific applications in this area remain a subject of discussion. The riffle construction involves an array of decisions as to where they are to be located, what material is to be used (broken rock, cobbles, concrete), in addition to other issues such as material diameter, the manner in which the material is laid out, riffle gradient, and possible use of an energy dissipator pool [Bojarski et al. 2005, Plesiński and RadeckiPawlik 2018a, b, Radecki-Pawlik 2011, Tamagni et al. 2010, Torre 2001]. A variety of different riffles are used in Poland and elsewhere in the world. How they function in the channel is often to be determined. Interdisciplinary studies are conducted with respect to the riffle functioning. The goal is to eliminate construction mistakes and help improve these structures for future use. Modeling experiments are also conducted in laboratories. The main issues of interest include the riffle stability, channel segment stability, and relationship with main hydraulic parameters [Plesiński and Radecki-Pawlik 2018a, b, Ślizowski et al. 2008].

It has been observed that well-made riffles tend to be damaged by flood flows. This is often due to the inability to reproduce all environmental conditions in the course of laboratory research in order to perfect the structural design [Bezzola 2005, Tamagni et al. 2010]. Attempts were made to establish the effect of channel roughness upstream of riffles on flow hydraulics [Ślizowski 1976]. Studies were also undertaken to determine the extent to which the stream channel bed becomes washed away below the given structure [Ślizowski 1992, 1993]. Some papers focused on the ecological aspects of riffle functioning. Tamagni et al. [2010] noted the problem of securing appropriate water levels and velocity of flow in order to sustain aqueous organisms migrating via riffles at high water stages and low water stages.

Most of the above-mentioned studies focused on a single riffle model. There is a lack of studies on the effects of riffle sequences on water flow dynamics. The purpose of the paper is to show the changes in water flow and sediment movement conditions in a $2.5 \mathrm{~km}$ section of river featuring a sequence of artificial riffles. The effects of riffles were examined under normal discharge conditions and extreme discharge conditions, as in the case of discharge occurring one year after the creation of the studied riffles in the course of check dam lowering. The dam was situated immediately above the studied reach. This flood event covered the entire studied reach along with its riffles with a layer of the sediment of variable thickness [Lenar-Matyas et al. 2015].

\section{CHARACTERISTICS OF THE STUDY REACH}

Krzczonówka Stream is a left bank tributary of the Raba River. Its spring is situated at an elevation of $740 \mathrm{~m}$ a.s.l. and its mouth at $329 \mathrm{~m}$ a.s.l. The Krzczonówka valley divides the Beskid Wyspowy and Beskid Makowski mountain ranges. Table 1 shows the selected characteristics of the studied stream and its catchment.

The study was conducted in the mouth section of the studied stream starting downstream of the lowered check dam $(\mathrm{km} 2+440)$ (Fig. 1). The mean diameter of sediment in this section of the channel was $0.040 \mathrm{~m}$ in 2013 [Project No. 214004-00].

A sequence of riffles was constructed in early 2013 in the studied segment - one every 120

Table 1. Characteristics of the Krzczonówka Stream

\begin{tabular}{|l|c|}
\hline Catchment area & $87.6 \mathrm{~km}^{2}$ \\
\hline Length & $16.7 \mathrm{~km}$ \\
\hline Mean gradient & $18.3 \% 0$ \\
\hline Mean grain size particles in channel & $0.040 \mathrm{~m}$ \\
\hline & $\mathrm{Q}_{1 \%}=190 \mathrm{~m}^{3} / \mathrm{s}$ \\
& $\mathrm{Q}_{2 \%}=170 \mathrm{~m}^{3} / \mathrm{s}$ \\
& $\mathrm{Q}_{5 \%}=135 \mathrm{~m}^{3} / \mathrm{s}$ \\
& $Q_{10 \%}=105 \mathrm{~m}^{3} / \mathrm{s}$ \\
& $Q_{50 \%}=40 \mathrm{~m}^{3} / \mathrm{s}$ \\
& $Q_{\text {average }}=0.62 \mathrm{~m}^{3} / \mathrm{s}$ \\
\hline
\end{tabular}




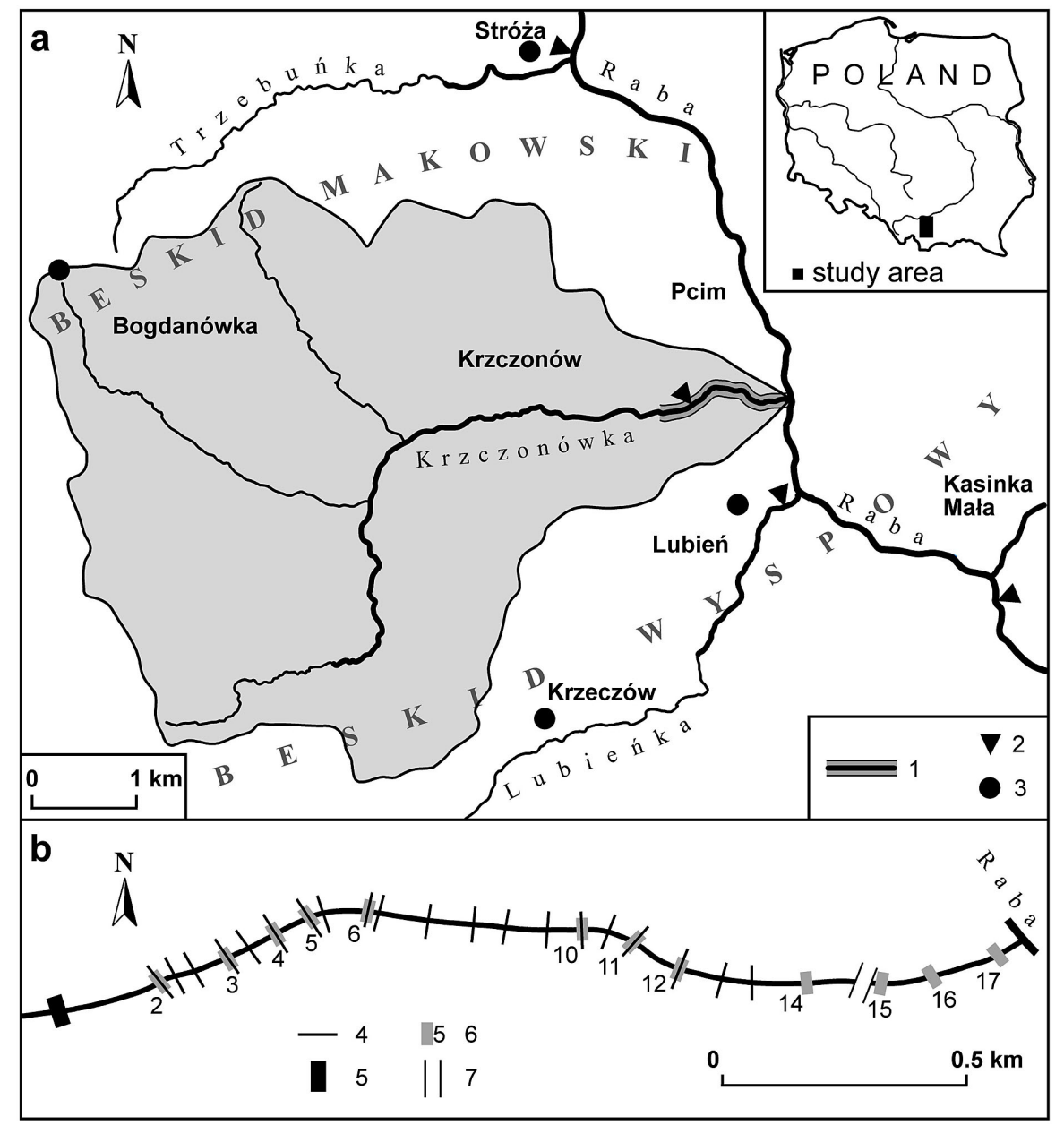

Figure 1. Location of the study area: $\mathrm{a}$ - the Krzczonówka River catchment, $\mathrm{b}$ - the studied channel segment; 1 - studied channel segment, 2 - gauging site, 3 - precipitation station, 4 - cross section, 5 - check dam, 6 - artificial riffle and its number, 7 - bridge

meters (approximately). The riffle sites were selected so that the crest of the riffle would be situated at the site of natural transition from pool to riffle (Fig. 2). Artificial riffles were not constructed in the segment between riffles 6 and 10, as natural riffles were present in this segment that did not need adjustment [Project No. 214004-00].
The new riffles elevated the crest of the existing riffles and were made of rocky particles of variable diameter, which was not stabilized using concrete. Only the density of the rock particles layers was increased using machines. The main body of the riffle consists of large blocks of broken rock (diameter: over $1 \mathrm{~m}$ ). The spaces between
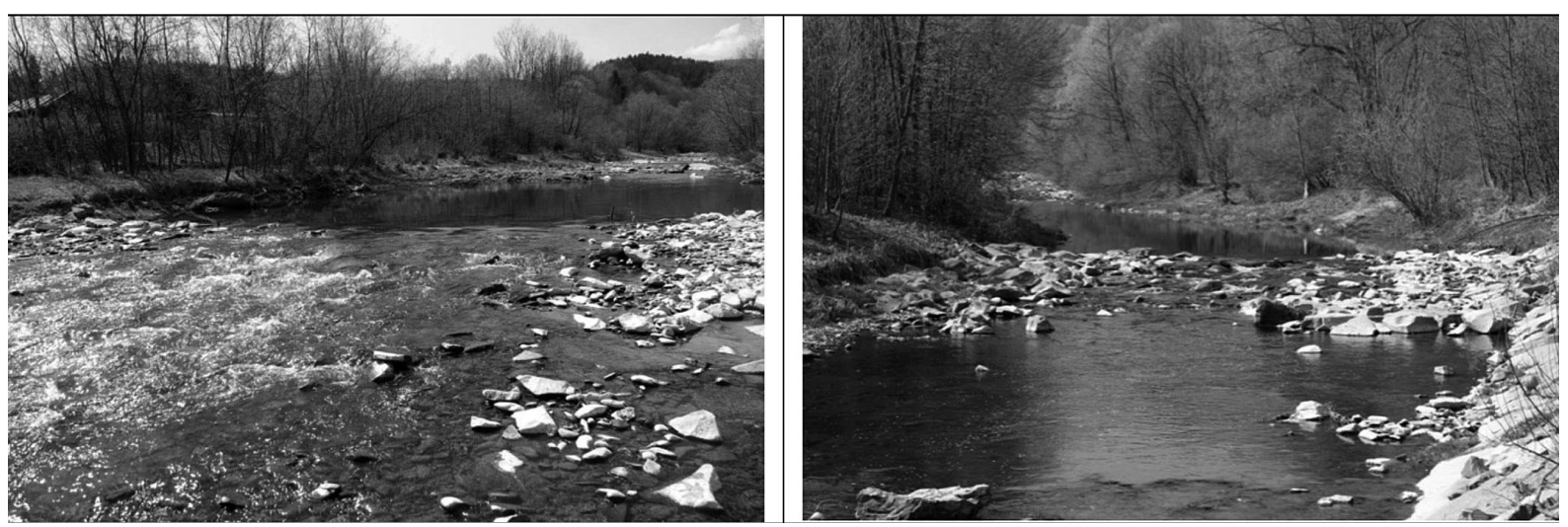

Figure 2. Two examples of artificial riffles on Krzczonówka Stream 
the large rocks were filled using finer particles of sediment that ranged from gravel mix to sand. The height of each body of the constructed riffles depends on the local conditions and ranges from 0.6 to $1.2 \mathrm{~m}$ (Fig. 3 ).

The segment between riffle no. 2 and riffle no. 12 was studied in detail. The segment from the dam to riffle no. 2 was omitted due to damage done to the segment shortly after the flood when it was excavated to reveal a buried water gauge, which was buried abruptly by the sediment from the reservoir. The cross sections studied here in 2014 did not reflect the natural changes in the channel. The segment downstream of riffle no. 12 was also omitted - due to the note that its transformation may have been assisted by the Raba River in the course of the studied extreme flood event. The Raba generated a wide flood zone in the area near the mouth of the Krzczonówka, which may have elevated the water levels in the latter as well.

\section{EXTREME RAINFALL EVENT - MAY 2014}

Heavy rainfall occurred abruptly in southern Poland in mid-May of 2014. The measured field data suggest that the distribution of rainfall in the Raba catchment was even (Table 2). This led to a substantially increased discharge in the Raba and its area tributaries. The highest discharge was noted at night between May 15 and 16 (Table 2).

In the context of catchment size and the even distribution of precipitation, it may be asserted that the differences recorded by gauging stations at Lubień and Krzczonów are large. The sediments released by the reservoir on Krzczonówka Stream covered a section of the channel with a water level gauge with a roughly one meter layer. This may have caused disturbances in the measurements and resulting data of low quality. This is why the data from the Krzczonów gauging station was omitted and maximum discharge for Krzczonówka Stream was assumed instead, interpolating the discharge values from the Kasinka Mała and Stróża gauging stations situated on the Raba River.

$$
\begin{aligned}
& q_{\text {max }}=\frac{Q_{D \max } Q_{\text {Gmax }}}{2 a}=1.48\left[\mathrm{~m}^{3} / \mathrm{s} / \mathrm{km}^{2}\right] \\
& \mathrm{Q}_{\text {xmax }}=\mathrm{q}_{\max } \cdot \mathrm{A} x=133.52\left[\mathrm{~m}^{3} / \mathrm{s}\right]
\end{aligned}
$$

where: $q_{\max }-$ maximum unit discharge;

$Q_{D \max }-$ maximum discharge at downstream gauging station - Stróża;

$Q_{G \max }-$ maximum discharge at upstream gauging station - Kasinka Mała;

$Q_{\text {xmax }}$ - maximum discharge at upstream gauging station - Krzczonów;

$A_{D}$ - total catchment area at the downstream gauging station;

$A_{G}$ - total catchment area at the upstream gauging station;

$A_{x}$ - total catchment area at the Krzczonów gauging station.

The calculated value corresponds to the discharge with an occurrence probability of about 5\% (Table 1).

\section{METHODS}

\section{Field measurements}

The studied stream course has been examined geodetically since 2013, including examination of its cross sections and water levels. The

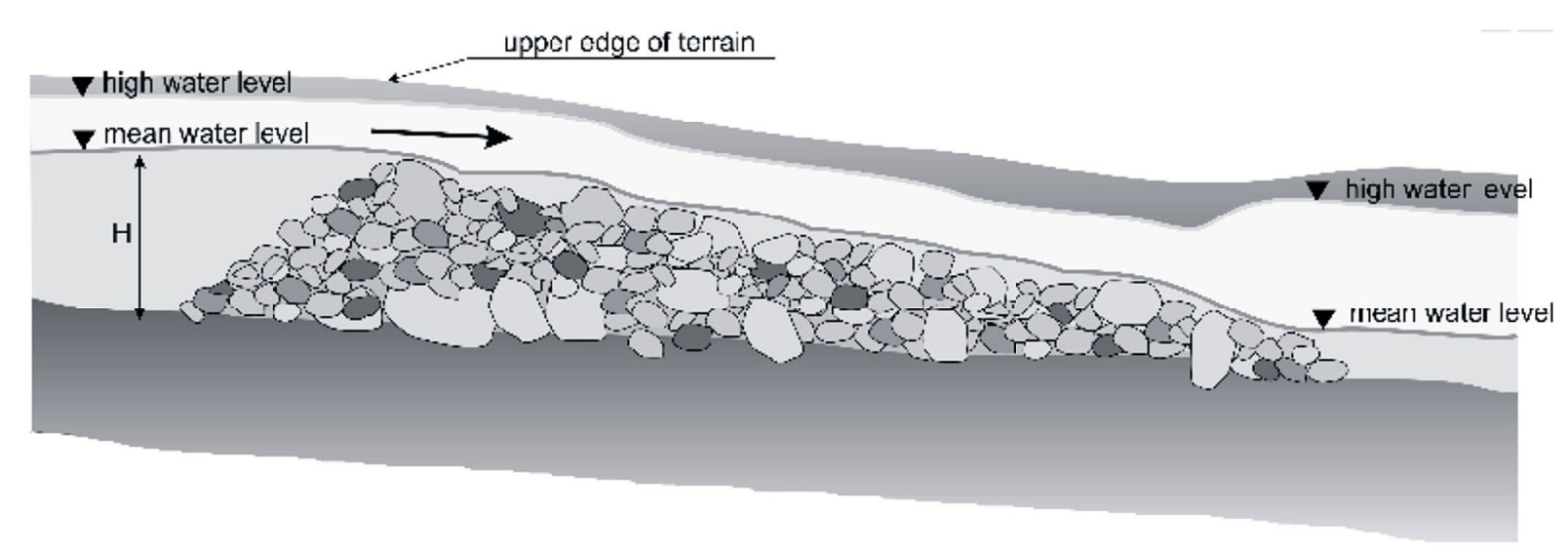

Figure 3. Sketch of an artificial riffle constructed on the Krzczonówka Stream - longitudinal profile 
Table 2. Maximum stream discharge and precipitation during the flood in May 2014 [IMGW data]

\begin{tabular}{|l|l|c|c|c|c|}
\hline \multicolumn{1}{|c|}{ Gauging station } & \multicolumn{1}{|c|}{ Stream } & $\begin{array}{c}\text { Catchment } \\
\text { area }\left[\mathrm{km}^{2}\right]\end{array}$ & $\begin{array}{c}\text { Precipitaton on } 15 \text { of } \\
\text { May 2014 }[\mathrm{mm} / \mathrm{day}]\end{array}$ & $\begin{array}{c}\text { Maximum } \\
\text { discharge }\left[\mathrm{m}^{3} / \mathrm{s}\right]\end{array}$ & $\begin{array}{c}\text { Probability } \\
\text { of occurrence }\left[\mathrm{m}^{3} / \mathrm{s}\right]\end{array}$ \\
\hline Kasinka Mała & Raba & 353.31 & no data & 243 & $\begin{array}{c}\text { Q10\% } \\
\text { Q50 } \%=90\end{array}$ \\
\hline Lubień & Lubieńka & 47.78 & 117.5 & 51.9 & $\begin{array}{c}\text { Q10\% } \\
\text { Q50 } \%=20\end{array}$ \\
\hline Krzczonów & Krzczonówka & 89.67 & no data & 254 & $\begin{array}{c}\text { Q0,1\% } \\
\text { Q1\% }=280\end{array}$ \\
\hline Stróża & Raba & 644.1 & 87.2 & 676 & $\begin{array}{c}\text { Q2 } \%=790 \\
\text { Q5\% }\end{array}$ \\
\hline Bogdanówka & Krzczonówka & 92.2 & 125.1 & no data & \\
\hline Krzeczów & Lubieńka & 47.8 & 94.6 & no data & \\
\hline
\end{tabular}

measurements were performed using a Topcon Hiper II GPS device. A total of 20 channel cross sections were examined along with adjacent areas from the check dam to the mouth of the river. The measurements were repeated in 2014 after a flood. Additional sites were also selected at the locations substantially altered relative to the year before. New sites were designated at the crest of natural and newly formed riffles as well as below them. The purpose of cross sections comparison is to identify trends in channel morphometry, in addition to their impact on the discharge conditions and capacity in a given stream course.

\section{D Model simulation}

The analyses of changes in water discharge conditions and sediment movement in the Krzczonówka in this study were conducted via a onedimensional mathematical model [Łapuszek et al. 2007, Paquier 2003]. The model solves the problems associated with undetermined water movement patterns in relation to sediment transport in a stream channel. It employs a continuity equation and the Saint Venant equations to examine the water discharge in relation to sediment shifts and is based on the classic sediment transport formula by Meyer-Peter and Müller [Meyer-Peter et al. 1948]. The material that forms the channel bed is represented by D50 diameter. The model was used to determine water levels for all examined cases. Next, the depth at which sediment movement starts was calculated for selected stream course with different slopes. The next step consisted of the determination of sediment transport rates in selected time intervals. Channel geometry was examined with and without riffles.

Hydraulic calculations were performed for the following discharge values:
- discharge calculated for Krzczonówka Stream with a peak $\mathrm{Q}=133.52 \mathrm{~m}^{3} / \mathrm{s}$, which most likely occurred during a flood in May 2014,

- discharge resembling bankfull discharge with $\mathrm{Q}_{67 \%}=30 \mathrm{~m}^{3} / \mathrm{s}$.

Four study cases were taken into account in the calculations:

- I - channel with no riffles, discharge $\mathrm{Q}_{67 \%}=30 \mathrm{~m}^{3} / \mathrm{s}$;

- II - channel with no riffles, discharge $\mathrm{Q}=133.52 \mathrm{~m}^{3} / \mathrm{s}$;

- III - channel with riffles, discharge $\mathrm{Q}_{67 \%}=30 \mathrm{~m}^{3} / \mathrm{s}$

- $\mathrm{IV}^{67 \%}$ - channel with riffles, discharge $\mathrm{Q}=133.52 \mathrm{~m}^{3} / \mathrm{s}$.

The calculation results were used to analyze the effects of new riffles in the channel on the changes in water levels and sediment transport rates in relation to different discharge values. The relationship between the sediment transport rates and selected parameters of channel geometry was analyzed as well.

\section{RESULTS}

The calculation results show that water discharge values and sediment transport rates vary from one segment to another between the riffles in the studied channel (Fig. 4).

Longitudinal profiles were fitted with channel bottom depths before and after the construction of artificial riffles. The sites of the riffles were also denoted on diagrams along with the water levels for four cases for which calculations were provided (Fig. 4a). The diagrams below the longitudinal profile show the water slopes as well as sediment transport rates for sections between 
selected cross sections before and after the construction of riffles (Fig. 4b, c). All relationships were shown for two discharge values: discharge $\mathrm{Q}_{67 \%}=30 \mathrm{~m}^{3} / \mathrm{s}$ (called bankfull from now on) and discharge $\mathrm{Q}=133.52 \mathrm{~m}^{3} / \mathrm{s}$. The latter was most likely present in May 2014 when the material collected in the check dam reservoir was released called flood discharge from now on.

In the channel with no riffles, the water slope does not vary significantly for the two studied discharge values (Fig. 4B). The situation is different in the channel with riffles - the slope is smaller for bankfull discharge than for flood discharge. On the other hand, the sections between riffles 4 and 6 , where the slope is much smaller are characterized with discharge $\mathrm{Q}=133.52 \mathrm{~m}^{3} / \mathrm{s}$.
The water slopes are smaller when riffles are used - this is true for almost every section and at both studied discharge values (Fig. 4B). This finding further confirms the effectiveness of artificial riffles. The opposite trend was noted only in the section between riffles 6 and 10 at flood discharge. This may be explained by valley geometry. At site no. 6, the increase in water level is much higher than that for site no. 10, which leads to an abrupt increase in the water slope. This may be observed on an orthophotomap with the flood zone noted (Fig. 5).

The decrease in the transport rate is readily observable following the construction of artificial riffles (Fig. 4C). The sediment transport virtually ceases to occur between riffles 4 and 6 , due

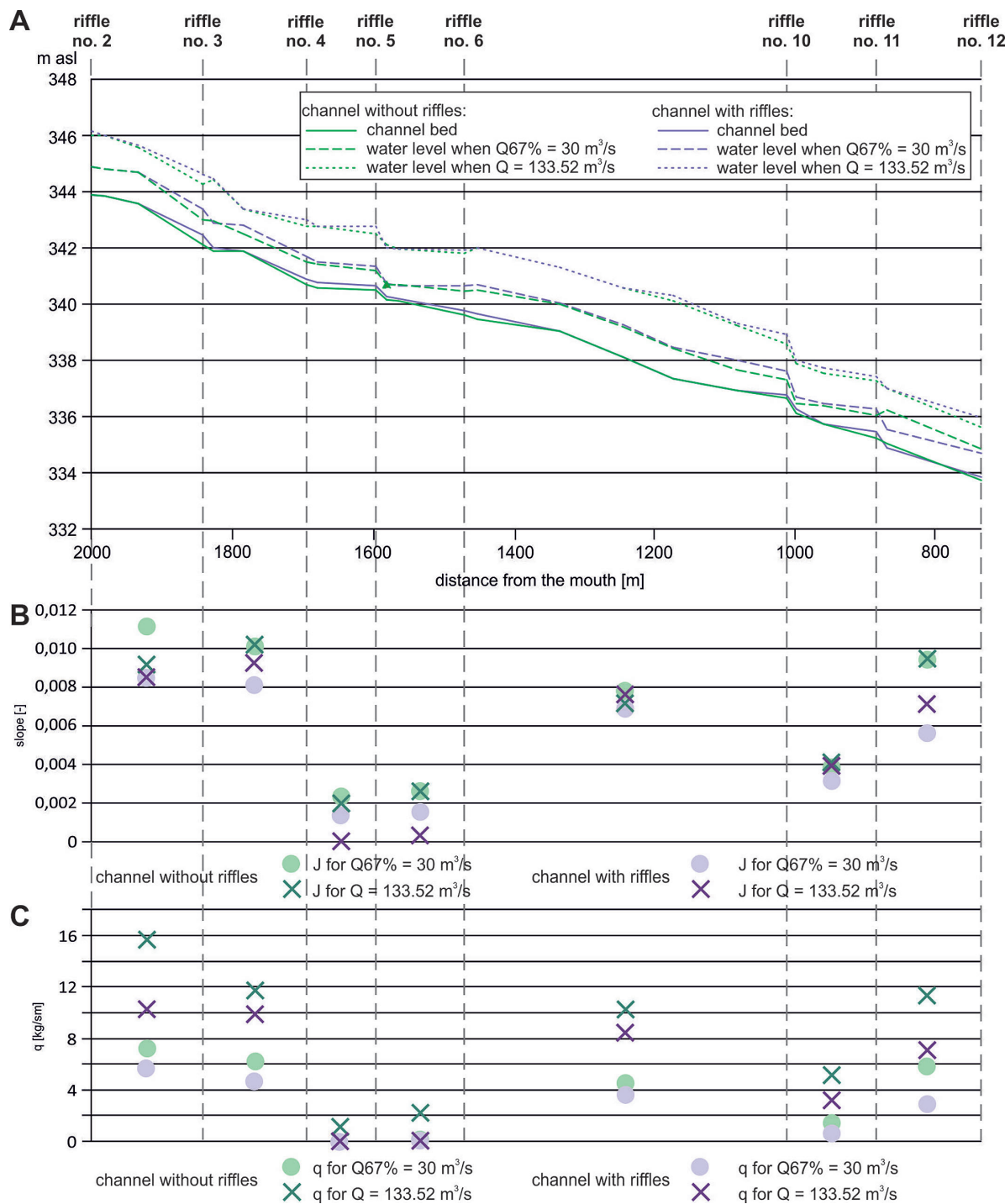

Figure 4. The effect of riffle sequence in the Krzczonówka Stream on water slopes and sediment transport rates for two discharge values: $\mathrm{Q} 67 \%=30 \mathrm{~m}^{3} / \mathrm{s}$ and $\mathrm{Q}=133.52 \mathrm{~m}^{3} / \mathrm{s}$ : A - longitudinal profile of channel bottom and water level before and after construction of artificial riffles; $\mathrm{B}$ - water slopes for the sections between individual cross-sections before and after the construction of riffles; $\mathrm{C}$ - sediment transport rates for sections between individual cross sections before and after the construction of riffles 


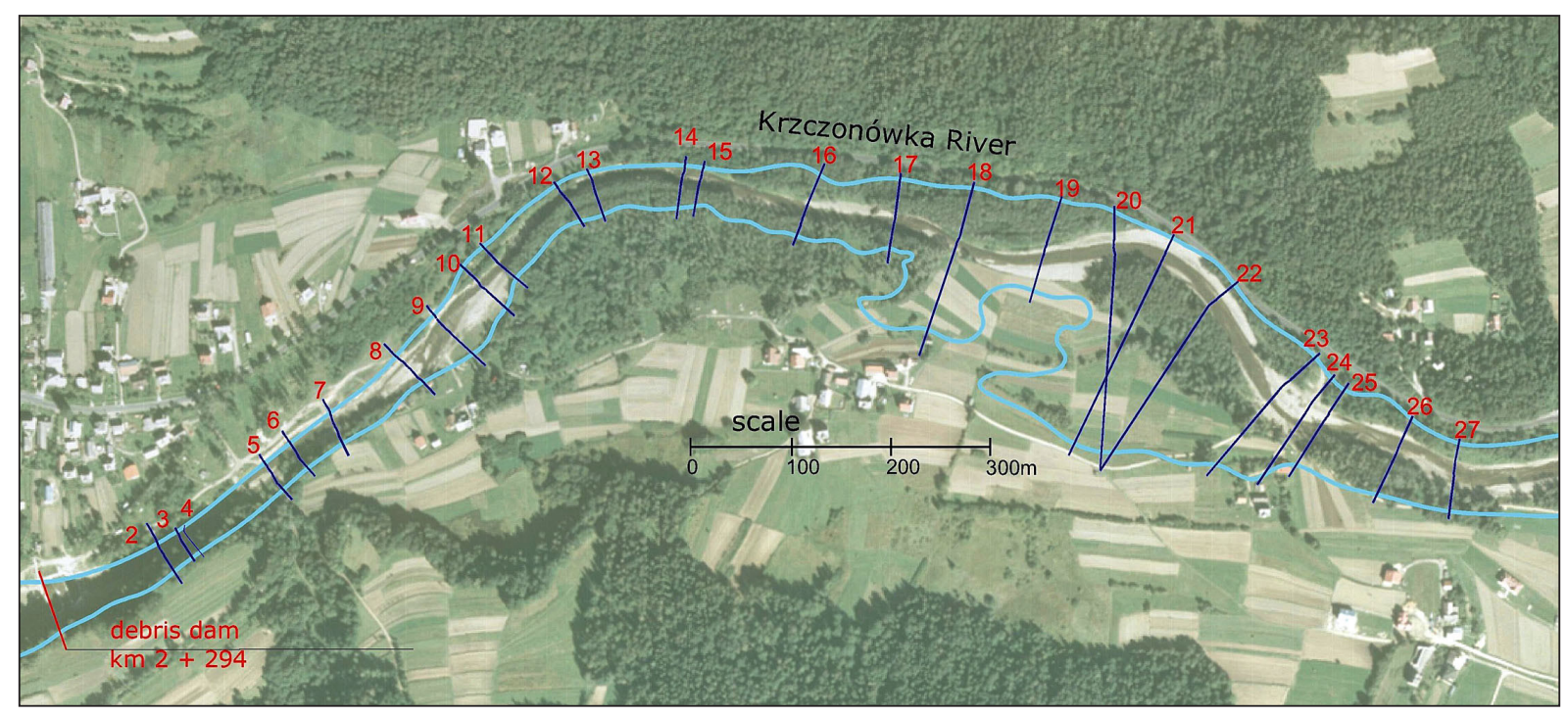

Figure 5. The Krzczonówka Stream studied course with pointed out flooding area

to very small water slope. An observable transport rate was possible in this section only prior to the construction of riffles at flood discharge (Fig. 4C). Riffles tend to substantially reduce the sediment transport rates, especially at higher discharge values (Fig. 4C).

In addition, the relationship between the characteristic stream section parameters was examined in relation to the presence and absence of riffles. The following relationships were examined:

- distance between riffles and the sediment transport rate and water slope for each analyzed stream segment (between particular riffle),

- width of the water surface at each given discharge value and the sediment transport rate and water slope for each analyzed stream segment (Fig. 6).

The first diagram illustrates varying increases in the sediment transport rates with the increasing distance between riffles (Fig. 6A). The growth in the transport rate is smaller in the channel with riffles versus the channel without riffles. This is true for both bankfull discharge and discharge at $133.52 \mathrm{~m}^{3} / \mathrm{s}$. Similar tendencies are visible in the relationship between the distance between riffles and water slope (Fig. 6B). However, a larger difference is only observable in the case of bankfull discharge. The differences observed at discharge $=133.52 \mathrm{~m} 3 / \mathrm{s}$ are less easily discernible. The pattern is completely different in relation to the width of the water surface (Fig. 6C, D). It is quite similar for bankfull discharge for both diagrams - a vertical line. It may be asserted that when discharge is contained within the main stream channel, the width of the water surface does not affect the sediment transport or water slope. This is because the channel has similar width along the entire studied section. The differences become apparent at higher discharge that inundates the flood plain. The upper part of the valley is compact, while the banks of the main channel are high and steep. Lower parts are flatter and the flood plain is very wide up to $150 \mathrm{~m}$. This may be observed by looking at the attached orthophotomap (Fig. 5). Both transport rates and water slopes decline with increasing width of the water surface - up to the point where the water surface reaches about 90 meters in width. The tendency reverses at greater widths of the water table - leading to an increase in sediment transport rates. The amount of data is too limited and the number of calculations too small to draw meaningful conclusions regarding this problem; however, it does suggest where further research is needed. It is necessary to identify the optimal parameters for artificial riffles in stream channels.

\section{DISCUSSION AND CONCLUSION}

The research literature on the sequences of artificial riffles and their effects on stream channels and sediment transport is quite poor. Hence, this paper attempts to compare a sequence of artificial riffles constructed in 2013 with natural riffle-pool sequences present in rivers and streams with gravel beds. 
A

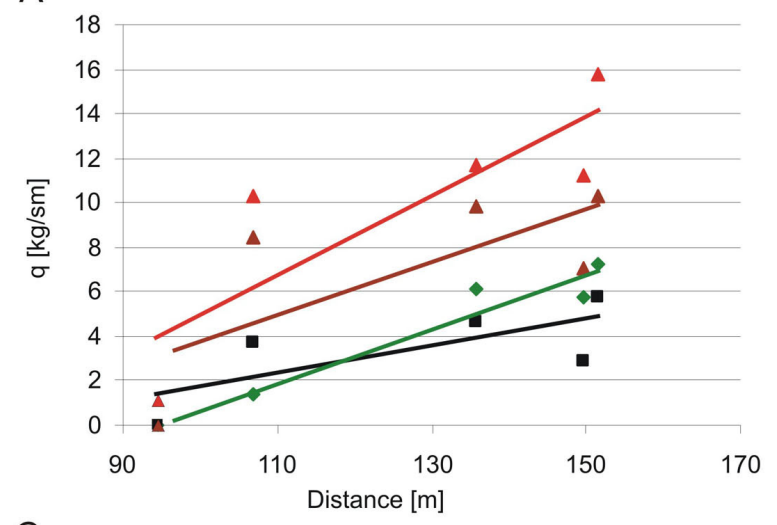

C

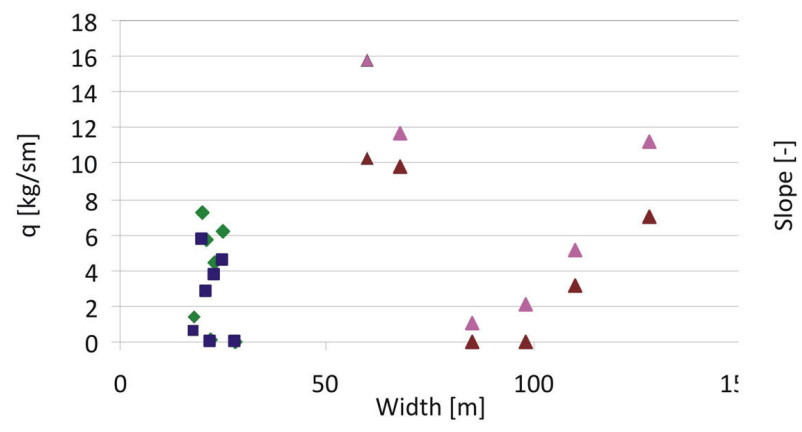

B

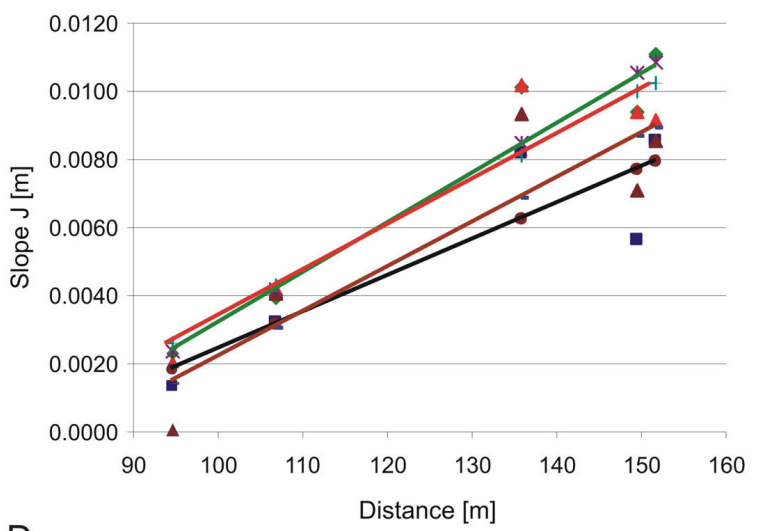

D

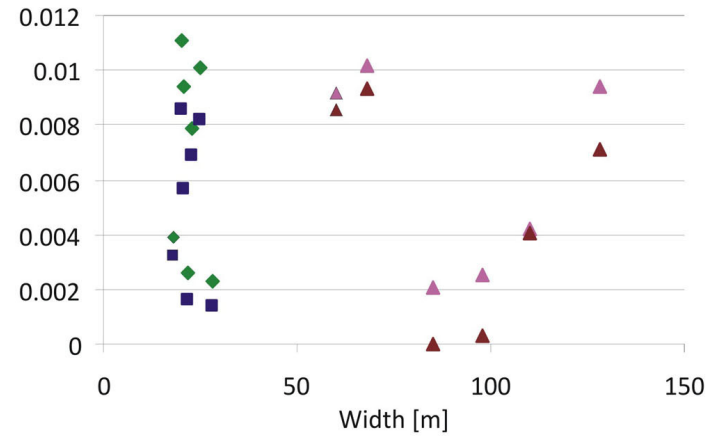

Figure 6. The relationships between: A) sediment transport rate and distance of the stream course; B) water slope and distance; C) sediment transport rate and width of the water surface; D) water slope and width of the water surface (computed for four study cases)

The studies on the relationships between the morphological parameters of riffles have been conducted since the 1950s. Proposals of empirical relationships between the riffle height, channel bed gradient, and distance between subsequent riffles do exist [Judd and Peterson 1969].

Research showed that the distance between riffles is related to the width of the channel, and in most cases represents a 5-7 multiple of this value [Keller et al. 1978, Radecki 2009]. This rule was also applied in the studied section of Krzczonówka Stram. The segment between riffle no. 6 and riffle no. 10 is longer due to the presence of natural riffles in-between. The latter were not upgraded as part of stream maintenance and were not included in the study calculations.

Whittaker [1987] studied the sediment transport in streams with sequences of steps, noting that the sediment transport in the study area did not follow a set pattern and varied with distance and time. The transport rate depended first and foremost on the influx of sediment, rather than on changes in channel bed morphology. Yu et al. [2012] disagree in the case of a segment of a mountain stream given three different streambed scenarios: welldeveloped, partly developed, flat bed. Their research showed that the transport rate declines with the increasing complexity of channel bed relief. These results confirm the validity of installations of artificial riffles in the geomorphologically poor form of erosive channel, as a way of reducing excessive sediment transport.

Cook et al. [2017] were able to show that the differences in the width of alluvium channels may play a deciding role in the sediment transport rate along the length of the channel. Given the same gradient, narrow channels are more efficient at low discharge, while wide channels transport more sediment at high discharge [Cook et al. 2017]. The observations of the Krzczonówka channel showed that the width of the water surface at bankfull discharge does not affect the sediment transport rate at all. This may be due to the fact that the bankfull width of the channel does 
not change to a major extent along this particular section. Variability in the transport rate appears only at higher discharge, where valley geometry plays a significant role. Some researchers believe that the transport rate is not a simple increasing or decreasing function of channel width, but that there is some type of optimal channel width with respect to the transport rate [Carson and Griffiths 1987]. In such optimal cases, the transport rate assumes a maximum value. The research on Krzczonówka Stream confirms the nonlinear nature of changes in the transport rate. The data available for this stream segment are not sufficient to determine an optimal channel width, but this relationship may be employed in future studies when designing artificial riffle sequences.

A comparison of water slopes for various discharge values shows a pattern typical of channels with riffle-pool sequences. At high water stages, the water surface is more even, while at low water stages, it is more determined by channel bed forms [Charlton 2008, Radecki-Pawlik 2011]. In the absence of riffles, the differences between slope values for the water surface at different discharge values are much smaller.

The main role of riffles is to limit the sediment transport rate, which has occurred in Krzczonówka Stream. The sediment transport rate is lower for all the studied segments, both at bankfull and flood discharge, in relation to its value prior to artificial riffle construction. This is due to the varying channel gradient and is consistent with stream channel hydraulics. The arrival of sediment in this case was dependent on the presence of a check dam, which was being modernized at the time. The presence of riffles halted most sediment transport along the studied stretch of stream. The only site not to experience deposition was the area of riffle no. 10, where even some erosion was observed. The probable cause was insufficient bed load of the stream at its large transport capacity here. It should be noted that a very small channel gradient and a very low potential sediment transport rate are present upstream, between riffle no. 4 and riffle no. 6 . The stream was overloaded with the sediment from the reservoir, most of which became deposited here under these specific conditions resulting in much less bedload further downstream.

The selection of appropriate parameters at the riffle location and construction helps determine their functionality in the course of variable discharge. By creating models for various scenarios, we are able to regulate the deposition and transport processes to some extent depending on the goal we are trying to achieve. Calculations need to consider the geometry of the entire flood zone and not just the stream channel itself. The condition for the reliability of such scenarios, however, is a permanent source of material supply to the channel section with riffles.

\section{REFERENCES}

1. Bezzola G.R., Semadeni N., Janisch T. 1986. Rampen und Schwellen - künstliche Schnellen. Mitteilungen der Ver-suchsanstalt für Wasserbau, Hydrologie und Glaziologie, ETH Zürich, Nr. 190, 241-254 (in German).

2. Bojarski A., Jeleński J., Jelonek M., Litewka T., Wyżga B., Zalewski J. 2005. Zasady dobrej praktyki w utrzymaniu rzek i potoków górskich, Ministerstwo Środowiska. Departament Zasobów Wodnych (in Polish).

3. Carson M.A., Griffiths G.A. 1987. Influence of channel width on bed load transport capacity, Journal of hydraulic engineering 113/12.

4. Charlton R. 2008. Fundamentals of fluvial geomorphology. Taylor\&Francis, London.

5. Cook K., Turowski J., Hovius N. 2017. Effect of channel width variation on sediment transport in mixed alluvial-bedrock rivers - from case study to concept. Geophysical Research Abstracts 19, EGU General Assembly.

6. Judd H.E., Peterson D. F. 1969. Hydraulics of large bed element channels. Utah Water Research Laboratory, College of Engineering, Utah State Univ, Longan, Utah.

7. Keller E.A., Melhorn W.N. 1978. Rhytmic spacing and origin of pools and riffles. Geological Society of America Bulletin, 89, 723-730.

8. Lenar-Matyas A., Korpak J., Mączałowski A. 2015. Influence of extreme discharge on restoration works in mountain river - the case study of the Krzczonówka River (Southern Poland). Journal of Ecological Engineering.;16(3):83-96. doi:10.12911/22998993/2941.

9. Łapuszek M., Lenar-Matyas M. 2013. Utrzymanie i zagospodarowanie rzek górskich. Wyd. Politechnika Krakowska, Kraków.

10. Łapuszek M., Paquier A. 2007. Practical Application of 1-D Sediment Transport Model, Archives of Hydro-Engineering and Environmental Mechanics, Vol. 54, no 4: 183-198.

11. Meyer-Peter E., Müller R. 1948. Formulas for bedload transport. Report on second meeting of IARH. IAHR, Stockholm: 39-64. 
12. Mooney D.M., Holmquist-Johnson C.L., Broderick S. 2007. Rock ramp design guidelines. US Department of the Interior, Bureau of Reclamation, Technical Service Center Denver, Colorado.

13. Paquier A. 2003. What are the problems to be solved by a $1-\mathrm{D}$ river sediment transport model? Example of RubarBE software. Selected Problems of Water Engineering, Politechnika Krakowska Cemagref - results of cooperation, 9-11 October 2003, seminary, Cemagref Editions 2004, BP 44, 92163 Antony, France: 75-85.

14. Plesiński K., Radecki-Pawlik A. 2018a. Bystrza o zwiększonej szorstkości: rodzaje, przykłady z praktyki, hydraulika, projektowanie i problemy eksploatacyjne. Wyd. Uniwersytet Rolniczy w Krakowie (in Polish).

15. Plesiński K., Radecki-Pawlik A. 2018b. Block ramps: a field example, [in:] A Radecki-Pawlik, Pagliara S., Hradecky S. (eds.), Open Channel Hydraulics, River Hydraulics Structures and Fluvial Geomorphology for Engineers, Geomorphologists and Physical Geographers, Taylor and Francis Group.

16. Project No. 214004-00. 2011.Tarliska Górnej Raby, Opis Techniczny, Ove Arup \& Partners International Ltd Sp. z o. o. Oddział w Polsce (in Polish).

17. Radecki-Pawlik A. 2009. Bystrza jako bliskie naturze rozwiązania utrzymania koryt rzek i potoków górskich. Nauka Przyroda Technologie. Uniwersytet Przyrodniczy w Poznaniu 3.3 (in Polish).

18. Radecki-Pawlik A. 2011. Hydromorfologia rzek i potoków górskich. Działy wybrane. Wyd. Uniwersytetu Rolniczego Kraków (in Polish).

19. Ślizowski R. 1976. Warunki stabilności koryt rzecznych zabudowanych stopniami niskich spadów. Akademia Rolnicza w Krakowie, Katedra Inżynierii Wodnej, praca doktorska, maszynopis Kraków (in Polish).

20. Ślizowski R. 1993. Bystrza o zwiększonej szorstkości jako element zabudowy potoków górskich (Rapid hydraulic structures as an element of river engineering works), Rozpr. hab. nr 181, Zesz. Nauk. AR w Krakowie (in Polish).

21. Ślizowski R. 1992. Badania modelowe wpływu różnych rozwiązań konstrukcyjnych bystrzy o zwiększonej szorstkości na deformacjê nieumocnionego dna koryta poniżej bystrza. Roczniki Nauk Rolniczych, PAN seria F, tom 83, z. $1 / 2$, 17-29 (in Polish).

22. Ślizowski R., Radecki-Pawlik A., Huta K. 2008. Analiza wybranych parametrów hydrodynamicznych na bystrzu o zwiększonej szorstkości na potoku Sanoczek. Infrastruktura i Ekologia Terenów Wiejskich, 2, 47 - 58 (in Polish).

23. Tamagni S., Weitbrecht V., R. Boes R. 2010. Design of unstructured block ramps - a state of the art review. Proceedings River Flow, Braunschweig, Germany, $729-736$.

24. Torre A. 2001. Stream Stabilisation. Water and Rivers Commission. Report RR, 10.

25. Whittaker J.G. 1987. Sediment Transport in Steppool Streams. [in:] Thorne C.R., Bathurst J.C., Hey R.D. (red.). "Sediment Transport in Gravel-Bed Rivers. John Wiley \& Sons, New York, 545-579.

26. Yu G., Wang Z., Huang H.Q., Liu H., Blue B., Zhang K. 2012. Bed load transport under different streambed conditions - a field experimental study in a mountain stream. International Journal of Sediment Research 27, 426-438. 